\title{
Snake venom cardiotoxin induces G-actin polymerization
}

\author{
Yee-Hsiung Chen and Sin-Tak Chu \\ Institute of Biochemical Sciences, College of Sciences, National Taiwan University, \\ and Institute of Biological Chemistry, Academia Sinica, Taipei (Taiwan, China)
}

(Received 25 January 1988)

Key words: Snake venom; Cardiotoxin; Actin polymerization; (Rabbit skeletal muscle)

\begin{abstract}
Snake venom cardiotoxin showed the ability to induce polymerization of G-actin from rabbit skeletal muscle in a low ionic strength buffer composed of $0.2 \mathrm{mM} \mathrm{CaCl} / 0.2 \mathrm{mM} \mathrm{ATP} / 0.5 \mathrm{mM}$ mercaptoethanol / 2.0 $\mathrm{mM}$ Tris-HCl, pH 8.0. The activity was enhanced greatly when $0.4 \mathrm{mM} \mathrm{MgCl}_{2}$ was present in the buffer and could be inhibited if $G$-actin was preincubated with deoxyribonuclease I. Furthermore, the DNAase could also partially depolymerize actin polymer previously formed by the interaction of G-actin with the toxin.
\end{abstract}

Snake venom cardiotoxin is a basic globular protein [1]. It shows a variety of biological activities toward cells of different origins [2]. It is non-neurotoxic but can cause cardiac arrest, muscle contraction, membrane depolarization and cytolysis [2]. Thus, the toxin has been described also as a cytotoxin, a direct lytic factor, a membrane-active polypeptide and a membrane-disruptive polypeptide [3-5]. Despite many descriptions of the effects of the toxin on experimental preparations [2], its mechanism of action is far from clear. In this communication, we demonstrate that the toxin is able to induce actin polymerization under conditions in which actin is normally in the monomeric form.

Actin is in the monomeric form (G-actin) in a low ionic strength buffer composed of $0.2 \mathrm{mM}$ $\mathrm{CaCl}_{2} / 0.4 \mathrm{mM} \mathrm{MgCl}_{2} / 0.2 \mathrm{mM}$ ATP $/ 0.5 \mathrm{mM}$ mercaptoethanol $/ 2.0 \mathrm{mM}$ Tris- $\mathrm{HCl}, \mathrm{pH} 8.0$ [6]. The process of actin polymerization can be monitored by measuring the increase of either viscosity or absorbance of the actin solution as filaments

Correspondence: Y.-H. Chen, Institute of Biochemical Sciences, National Taiwan University, Taipei, Taiwan, China.
(F-actin) are formed [7-9]. Fig. 1 shows the actin polymerization induced by the toxin. The viscosity or the absorbance of the G-actin solution (500 $\mu \mathrm{g} / \mathrm{ml}$ ) increased rapidly when $2.3 \mu \mathrm{M}$ toxin was added. After $3 \mathrm{~min}$ of incubation, the viscosity or the absorbance reached a maximum level. Under similar conditions, but in the absence of $\mathrm{Mg}^{2+}$, the polymerization was greatly reduced. The polymerization was apparently a function of the amount of toxin added (Fig. 2).

Deoxyribonuclease I (DNAase I) is known to bind tightly to G-actin [11]. We found that preexposure of G-actin to DNAase I suppressed the polymerization induced by the toxin. Very slight polymerization could be induced by the toxin when G-actin and DNAase $I$, in equimolar concentrations, were preincubated in the low ionic strength buffer (Fig. 3). On the other hand, the DNAase could partially depolymerize the actin polymer previously formed by the interaction of G-actin and the toxin (Fig. 3).

In conclusion, the characteristics of the toxininduced actin polymerization are very similar to the actin polymerization induced by high ionic strength $\mathrm{KCl}$, as reported previously [12]. Whether the ability of the toxin to induce actin polymeriza- 


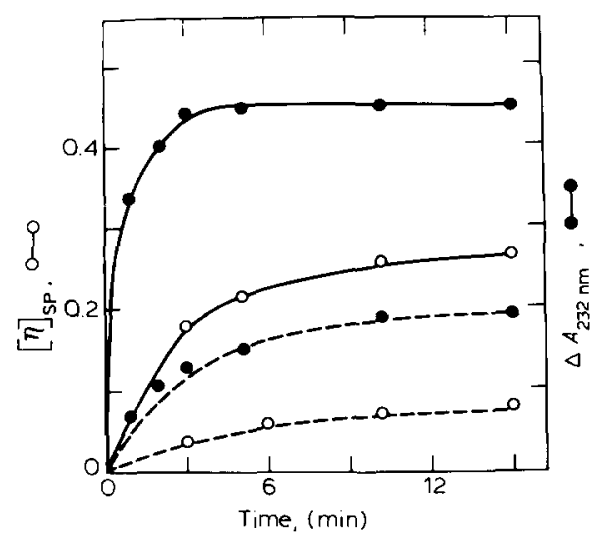

Fig. 1. Cardiotoxin-induced G-actin polymerization. Actin was prepared from rabbit skeletal muscle [7]. Cardiotoxin was purified from Formosan Cobra/Naja naja atra venom [10]. At $24^{\circ} \mathrm{C}, 500 \mu \mathrm{g}$ actin in $1 \mathrm{ml}$ of a low ionic strength buffer was incubated with the toxin at a final concentration of $2.3 \mu \mathrm{M}$. The buffer was composed of $0.2 \mathrm{mM} \mathrm{CaCl}_{2} / 0.4 \mathrm{mM}$ $\mathrm{MgCl}_{2} / 0.2 \mathrm{mM}$ ATP $/ 0.5 \mathrm{mM}$ mercaptoethanol $/ 2.0 \mathrm{mM}$ Tris$\mathrm{HCl}, \mathrm{pH}$ 8.0. Actin polymerization was monitored by measuring the increase of either the viscosity $(O)$ or the absorbance of the solution $(\bullet)$ as reported previously $[8,9]$. Solid and dashed lines represent the polymerization in the presence and in the absence of $0.4 \mathrm{mM} \mathrm{MgCl}$, respectively. A control experiment showed no evidence of polymerization in the absence of added toxin.

tion plays any role in disturbing cellular activity awaits future study.

This work was supported by grant NSC77-

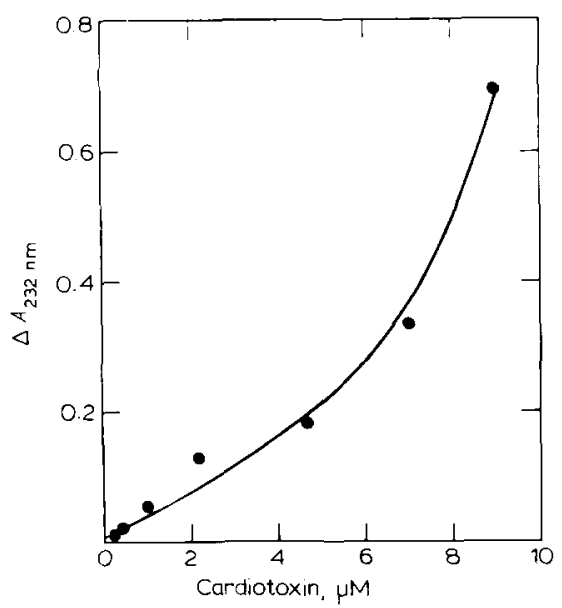

Fig. 2. Actin polymerization induced by various amounts of cardiotoxin. Cardiotoxin and $100 \mu \mathrm{g} \mathrm{G}$-actin were incubated at $24^{\circ} \mathrm{C}$ for $15 \mathrm{~min}$ in $1.0 \mathrm{ml}$ of the low ionic strength buffer as described in Fig. 1.

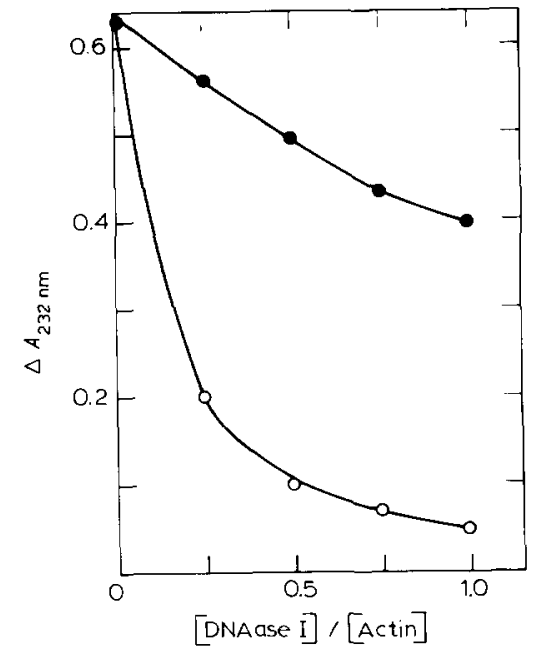

Fig. 3. DNAase I inhibited G-actin polymerization by cardiotoxin $(O)$ and depolymerized actin polymer previously formed by the toxin ( $\bullet$ ). In the first case, G-actin and various amounts of DNAase I were incubated at $24^{\circ} \mathrm{C}$ for $5 \mathrm{~min}$ in the low ionic strength buffer as described in Fig. 1. Cardiotoxin was then added and the reaction mixture was incubated at the same temperature for another $10 \mathrm{~min}$ before the extent of polymerization was determined. In the second case, the actin polymer, which was previously formed by the incubation of $\mathrm{G}$-actin and the toxin at $24^{\circ} \mathrm{C}$ for $10 \mathrm{~min}$, was incubated with DNAase 1 at the same temperature for $5 \mathrm{~min}$ and the extent of actin polymerization was measured. In all experiments, the final concentrations were $8.4 \mu \mathrm{M}$ for the toxin and $100 \mu \mathrm{g} / \mathrm{ml}$ for $\mathrm{G}$-actin. The molar ratio of DNAase I to $\mathrm{G}$-actin varied from 0 to 1 .

0203-B001-01 from the National Science Council, Taipei, Taiwan, Republic of China. We thank Mr. Chan-Pin Lee for technical assistance.

\section{References}

1 Chen, Y.H., Pan, B.T. and Lee, C.P. (1982) Biochim. Biophys. Acta 702, 193-196.

2 Chang, C.C. (1979) Handbook of Experimental Pharmacology (Lee, C.Y., ed.), Vol. 52, pp. 309-376, Springer-Verlag, Berlin.

3 Chen, Y.H., Liou, R.F., Hu, C.T., Juan, C.C. and Yang, J.T. (1987) Mol. Cell. Biochem. 73, 69-76.

4 Condrea, E. (1979) Handbook of Experimental Pharmacology (Lee, C.Y., ed.), Vol. 52, pp. 448-472, Springer-Verlag, Berlin.

5 Tu, A. (1977) Venom: Chemistry and Molecular Biology, pp. 301-320, John Wiley and Sons, New York.

6 Bray, D. and Thomas, C. (1976) J. Mol. Biol. 105, 527-544.

7 Spudich, J.A. and Cooke, R. (1971) J. Biol. Chem. 246, 4866-4871.

8 Higashi, S. and Oosawa, F. (1965) J. Mol. Biol. 12, 843-865. 
9 Spudich, J.A. and Cooke, R. (1975) J. Biol. Chem. 250, $7485-7491$

10 Lo, T.B., Chen, Y.H. and Lee, C.Y. (1966) J. Chin. Chem. Soc. $13,25-37$.
11 Lazarides, E. and Lindberg, U. (1974) Proc. Natl. Acad. Sci. USA 71, 4742-4746.

12 Lin, D.C. and Lin, S. (1979) Proc. Natl. Acad. Sci. USA 76. 2345-2349. 